\title{
Ponticulus posticus. Lo que podría estar y no lo informamos
}

Ponticulus posticus. What can be there and we do not disclose

Jheferson Contreras-Grande ${ }^{1,2, a}$, Juan Padilla ${ }^{1, b}$
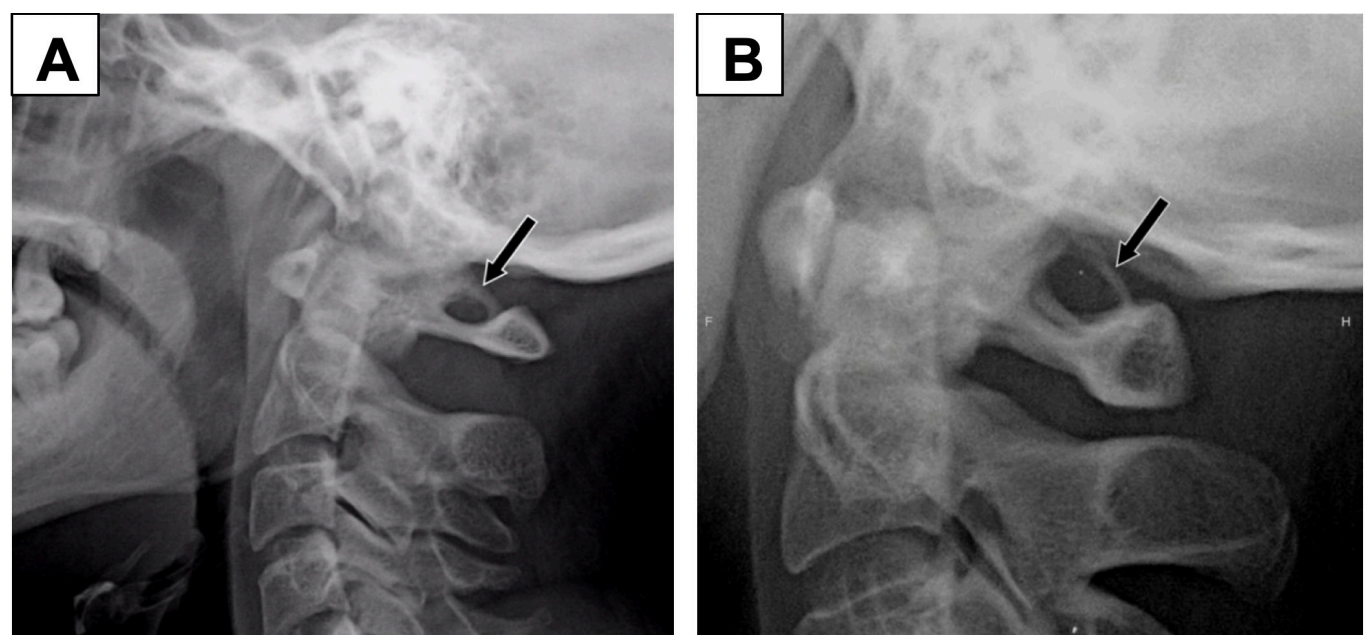

Se presentan dos pacientes, un varón de 35 años (A) y una mujer de 32 años (B), con cervicalgia crónica. En la radiografía lateral de columna cervical se encontró un puente óseo sobre el agujero de la arteria vertebral C1, característico de ponticulus posticus. Se postula que el ponticulus posticus surge de la osificación del segmento lateral del ligamento atlanto occipital superior, siendo unilateral o bilateral. Puede ser un hallazgo imagenológico incidental en un paciente asintomático; sin embargo, puede provocar isquemia vertebro-basilar, vértigo, cervicalgia y cefalea. Entre los hallazgos, en la radiografía lateral de cuello se evidencia una calcificación parcial o completa sobre el techo óseo del agujero de la arteria vertebral $\mathrm{C} 1$, tal como se encontró en ambos casos, por lo que es importante tener en cuenta este hallazgo e informarlo en pacientes que cursen con algunos de los síntomas descritos.

We present two patients, a 35-year-old male and a 32-year-old female with chronic cervicalgia. The lateral cervical X-ray showed a bone bridge over the vertebral artery hole at $\mathrm{C} 1$ characteristic of ponticulus posticus. This entity results from unilateral or bilateral ossification of the superior atlanto-occipital ligament. This ca be found incidentally in an asymptomatic patient or found in patients with vertebra-basilar ischemia, dizziness, cervicalgia and headache. Radiographic findings include partial or complete calcification over the bone ceiling of the $\mathrm{C} 1$ vertebral artery hole as found in our two cases. It is therefore to take in account these findings and share the diagnosis with patients.

\footnotetext{
Departamento de Imagenología, Hospital Nacional Edgardo Rebagliati Martins. Lima, Perú.

Facultad de Medicina, Universidad Peruana Cayetano Heredia. Lima, Perú.

Médico Residente de Radiología.

Médico Radiólogo
} 